\title{
The impact of high temperature and irradiance source on the efficiency of polycrystalline photovoltaic panel in a controlled environment
}

\author{
Julie C. Ogbulezie ${ }^{1}$, Armstrong O. Njok ${ }^{2}$, Manoj K. Panjwani ${ }^{3}$, Suresh K. Panjwani ${ }^{4}$ \\ ${ }^{1}$ Department of Physics, Faculty of Physical Sciences, University of Calabar, Nigeria \\ ${ }^{2}$ Department of Physics, Faculty of Physical Sciences, Cross River University of Technology, Nigeria \\ ${ }^{3}$ Department of Energy Systems Engineering, Sukkur IBA University, Pakistan \\ ${ }^{3}$ Renewable Energy School, North China Electric Power University, China \\ ${ }^{4}$ Department of Process and Environmental Engineering, Faculty of Technology, University of Oulu Finland, Finland
}

\section{Article Info \\ Article history: \\ Received Nov 1, 2019 \\ Revised Jan 23, 2020 \\ Accepted Feb 24, 2020}

\section{Keywords:}

Efficiency

Irradiance

Photovoltaic

Temperature

\begin{abstract}
Solar cells are highly sensitive to temperature, which affects its operating parameters. The study has its aim in accessing the impact of temperature (in excess above the maximum operating cell temperature) and irradiance source on the efficiency of polycrystalline photovoltaic (PV) solar panels in an environment where the temperature and irradiance level can be fully controlled. For the study to achieve its aim, a solar box and tungsten light bulbs were used to create an environment where the irradiance level and the temperature can be controlled. The solar panel was placed inside the solar box facing the light source while the irradiance level and temperature were measured and held constant. Results show a steady decrease in voltage with increasing temperature while the performance ratio and efficiency of the photovoltaic module followed a similar trend as that of voltage once the temperature exceeds the maximum operating cell temperature. Results also show the output voltage of the photovoltaic to be higher under the tungsten light than the sun, but the efficiency achieved by the photovoltaic under the sun far exceeds that obtained under the tungsten light.
\end{abstract}

Copyright $\odot 2020$ Institute of Advanced Engineering and Science. All rights reserved.

Corresponding Author:

Armstrong O. Njok,

Department of Physics, Faculty of Physical Sciences,

Cross River University of Technology (CRUTECH),

Calabar 540252, Nigeria.

Email: 1164200124@ncepu.edu.cn

\section{INTRODUCTION}

The efficiency of solar photovoltaics depends on the temperature it is subjected to, which is fundamentally a product of the ambient temperature as well as the level of sunlight [1]. Solar photovoltaic panels are designed to work best in certain temperature and atmospheric conditions known as standard test conditions (module temperature $25^{\circ} \mathrm{C}$, irradiance $1000 \mathrm{~W} / \mathrm{m}^{2}$ and AM 1.5) but since the weather is hardly constant, majority of panels do not operate under ideal conditions which they are designed for [2], so these standard test conditions do not match what is typically experienced under outdoor operations [3]. Moreover, under standard test conditions, the efficiency of solar photovoltaic panel decreases by about $0.40 \%-0.50 \%$ for each degree rise in temperature [4]. It is of enormous importance that engineers need to understand how solar photovoltaic panels respond to different temperature and atmospheric conditions so that the efficiency of solar photovoltaic panels that function in non-optimal conditions and atmospheres can be improved. Due to the rapid changes in our environment as a result of the massive consumption of fossil fuel, the world's 
attention is now directed toward green energy to save our planet. As a reliable source of renewable energy, solar energy has been identified as one of the most reliable sources of energy in the future [5]. Recently, solar energy has attracted attention around the globe and is currently playing a significant role in providing clean and sustainable energy [6].

Solar energy has been seen as a viable solution towards energy, environmental, and global challenges. The burning of fossil fuels consistently has led to humans suffering from an energy crisis accompanied by the pollution of our environment. Just like wind energy, solar energy has received intense attention because renewable energy is on tremendous focus [7]. One of the technologies in the renewable energy sector that have now become an established technology and experienced rapid growth over the years is the photovoltaic technology [8]. With this technology, the amount of carbon monoxide emitted to the atmosphere that comes from the burning of fossil fuel that disturbs the global carbon cycle [9] can be significantly reduced. However, the majority of the energy that humans consume today comes from fossil fuel, which has the sun as its origin, but for millions of years, it has been stored underneath the earth. Fossil fuels are predicted to be exhausted within 50-100 years from now if the current trend in which energy is demanded and consumed continues [10].

Ike [11] reported that there is an indirect proportionality between the ambient temperature of the locality and the output power produced by a photovoltaic system after carefully investigating the effect of temperature on the performance of solar photovoltaic systems in the eastern part of Nigeria. The result of the research further reveals that periods of high temperatures do not favor the conversion of solar energy to electrical energy. Omubo-pepple et al. [12] concluded that low temperature enables solar panels to function optimally by allowing an increase in output voltage, which triggers an increase in the output power as well as efficiency. These results came to light after investigations on the effect of solar flux and relative humidity on the efficient conversion of solar energy to electricity in Port Harcourt, Nigeria.

Njok \& Ogbulezie [13] studied the effect of temperature on polycrystalline solar panels installed close to a river and observed that an increase in current and efficiency is observed as the temperature of the panel is increased. Their result also reveals that the observed increase in efficiency as panel temperature increases is only up to the maximum operating cell temperature. Beyond this temperature, the efficiency begins to drop. Chaichan \& Kazem [14] analyzed the influence of solar intensity on photovoltaic modules in humid and hot weather conditions and concluded that wind effect on modules temperature was insignificant.

El-shaer et al. [15] studied how temperature affected the parameters of crystalline silicon solar modules and found that the current parameter is the parameter that is mostly influenced. Tobnaghi and Naderi [16] examined how the performances of solar cells are affected by temperature and solar radiation and revealed that the performance of solar cells is highly dominated by solar radiation. Gaur and Tiwari [17] analyzed the performance of photovoltaic modules of different solar cells for different climatic conditions and observed that for all the photovoltaic technologies utilized in the research, there is always a drop in efficiency first, before increasing with time from morning to evening in January and June.

Rani et al. [18] investigated how the performances of solar modules are affected by temperature and irradiance and showed that the output power of a solar panel increases with increasing solar irradiance. Syafiqah et al. [19] carried out a thermal and electrical study for photovoltaic modules incorporating cooling systems and reported that as the operating temperature of a photovoltaic panel increases, the output power decreases. Amelia et al. [20] investigated how temperature affected the output performance of PV modules and proved that the temperature of PV modules plays a significant role in power production. Leow et al. [21] reported that to achieve better output performance from photovoltaics, they should be operated in an atmosphere with considerable wind velocity.

Njok et al. [22] investigated how sunrise and sunset times cause monthly variations in photovoltaic efficiencies and reported that photovoltaics would be more efficient in months with low average relative humidity coupled with low panel temperature. Njok et al. [23] found that high solar power and solar flux positively enhance the performance of photovoltaics. Verayiah \& Iyadurai [24] conducted a comparison study on types of PV for grid connected photovoltaic power and discovered that ambient or cell temperature and solar irradiance influence the output performance.

Mansur \& Baharudin [25] conducted a performance analysis on a self-consumed solar PV system for a fully DC residential house and concluded that the temperature of the photovoltaic module, unused energy when battery to its full capacity coupled with battery and converter efficiencies contributes to losses of the system. The temperature in which a solar photovoltaic panel is exposed to plays a significant role in determining its efficiency. The daytime average temperature of states in Nigeria is higher than the temperature of the standard test condition as specified by the manufacturer. The ambient temperature of some states in Nigeria reaches temperatures that are close to the maximum operating cell temperature of photovoltaics, thereby prompting the need for this study. 
The novelty and aim of this research lie with the careful monitoring and investigation of the impact of temperature (in excess above the maximum operating cell temperature) and irradiance source on the efficiency of polycrystalline photovoltaic (PV) panels. For the study to achieve its aim, a solar box and tungsten light bulbs were used to create an environment where the temperature and irradiance level can be varied. The reason for this research is because the citizens and government of Nigeria are considering powering their homes using PV technology due to increasing oil price and environmental awareness. So, we intend to investigate how these panels will perform in some of the hottest states of Nigeria like Sokoto, which have recorded an ambient temperature of $47.2^{\circ} \mathrm{C}$. Some of these panels will be mounted on the rooftop while some will be pole mounted. For a pole-mounted and rooftop installation, the likely panel temperature can be obtained by multiplying the ambient temperature by 1.2 and 1.4, respectively [26].

\section{MATERIAL AND METHODS}

\subsection{Materials}

A solar box and a solar photovoltaic module with a power capacity of 130 watts made from polycrystalline silicon were used in the process. This module possesses a dimension of $1480 * 670 * 35 \mathrm{~mm}$ and is capable of delivering $18.10 \mathrm{~V}$ and $7.18 \mathrm{~A}$ at maximum voltage and current, respectively. A charge controller was used to enable steady and smooth charging of the lead-acid battery (12V-75AH). A digital multimeter (M890C+) synchronized with a thermocouple (K-type) for measuring temperature in Celsius was employed to accurately monitor the current, voltage, and temperature values from the module. Tungsten filament bulbs were utilized in the process as a source of radiation and heat to simulate the sun. A digital solar power meter (SM206), which is capable of measuring solar power in the British thermal unit (Btu) and Watt per square metre $\left(\mathrm{W} / \mathrm{m}^{2}\right)$, was also utilized to measure the level of irradiance the solar module was subjected to.

\subsection{Methods}

The solar photovoltaic module was placed inside the solar box with the temperature sensor installed on its surface while connecting cables linked to the output leads and the charge controller. The output of the charge controller was linked to the battery for the smooth charging of the battery. The battery was then connected to an inverter through which the load was powered. Measurements were taken as the temperature of the panel increased. For every significant increase in temperature, the voltage and current from the photovoltaic module were measured. The experiment was repeated ten (10) times, and the average was taken. After measurements were completed in the solar box, measurements were also taken under the sun at the same irradiance level that was set inside the solar box. From the measurements taken, the normalized power output efficiency was determined using in (1), the performance ratio was calculated from (2) while the maximum and measured power which the photovoltaic module can deliver was determined using in (3) and (4) respectively as shown by [27]. It has been shown by [13] that the short circuit current and the opencircuit voltage are been influenced by parameters like temperature and solar power as indicated in (5) and (6). Normalized power output efficiency:

$$
\eta_{\mathrm{p}}=\frac{P_{\text {mea }}}{P_{\max }} \times 100
$$

Performance ratio:

$$
\mathrm{PR}=\frac{\left(P_{\text {mea }} / P_{\text {max }}\right)}{\left(E_{\text {mea }} / 1000\right)}
$$

Maximum power:

$$
\mathrm{P}_{\max }=\mathrm{V}_{\max } \times \mathrm{I}_{\max }
$$

Measured Power:

$$
\mathrm{P}_{\text {mea }}=\mathrm{V}_{\text {mea }} \times \mathrm{I}_{\text {mea }}
$$

Short circuit current:

$$
I S C=\mathrm{bE}_{\mathrm{mea}}
$$


Open circuit voltage:

$$
\mathrm{Voc}=\frac{K T}{Q} \ln \frac{I s c}{I o}
$$

where $\mathrm{E}_{\mathrm{mea}}$ is the measured incident solar power (irradiance) on the photovoltaic module, $\mathrm{Q}$ is the electronic charge, $\mathrm{I}_{\mathrm{o}}$ is the saturation current, $\mathrm{T}$ is the absolute temperature of the photovoltaic module, $\mathrm{b}$ is a constant depending on the properties of the semiconductor junction, $\mathrm{K}$ is the Boltzmann constant. $\mathrm{P}_{\max }, \mathrm{V}_{\max }$, and $\mathrm{I}_{\max }$ are the maximum power, voltage, and current, respectively, that the module can give out. $\mathrm{P}_{\text {mea }}, \mathrm{V}_{\text {mea, }}$ and $\mathrm{I}_{\text {mea }}$ are the measured power, voltage, and current, respectively.

\section{RESULTS AND DISCUSSIONS}

The impact of increasing temperature on the voltage produced by the photovoltaic module under constant irradiance is shown in Figure 1. This figure shows a steady decrease in voltage as the temperature increases, confirming that an increase in temperature does not enhance voltage production from photovoltaic modules but rather decreases it, which is in agreement with work by Omubo-pepple et al. [12]. Figure 2 reveals how photovoltaic modules respond to increasing temperature in terms of current production. From the figure, an increase in current with increasing temperature is observed up to the maximum operating cell temperature $\left(47^{\circ} \mathrm{C}\right)$; beyond this temperature, a decrease in current coupled with erratic behavior is observed, which is found in agreement with work by Njok and Ogbulezie [13].

Figure 3 highlights the performance ratio of the photovoltaic module under constant irradiance with increasing temperature. The figure reveals that high temperature hampers the performance of photovoltaics. Figure 4 shows how the efficiency of the photovoltaic module is adversely affected by temperature. It reveals that temperature increase does not entirely enhance efficiency. This increase in efficiency as panel temperature increases is only up to the maximum operating cell temperature; beyond this temperature, the efficiency decreases as temperature increases. The results shown in Figure 4 are found in agreement with works by Omubo-pepple et al. and also with Njok \& Ogbulezie [12, 13].

Figure 5 reveals how the photovoltaic module responds to different sources of light with the same level of irradiance. The figure reveals a higher voltage been produced with tungsten light. Figures 6 and 7 show the current and efficiency produced by the photovoltaic module under different sources of irradiance, respectively. They reveal that under the sun, the photovoltaic module is more effective in current production and, thus, reaches a higher efficiency than with the tungsten light. This may be because under the sun, every part of the solar cell junction is entirely and evenly illuminated.

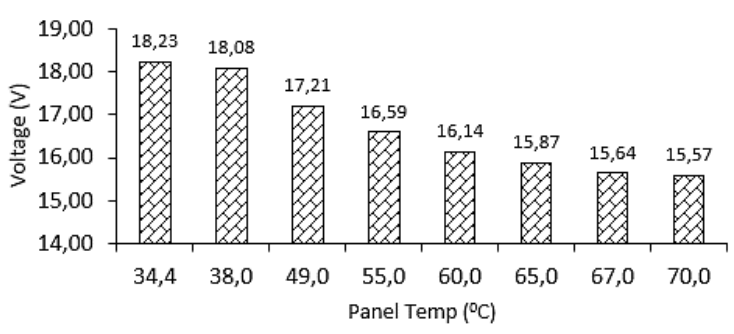

Figure 1. Voltage performance of the photovoltaic module with increasing temperature

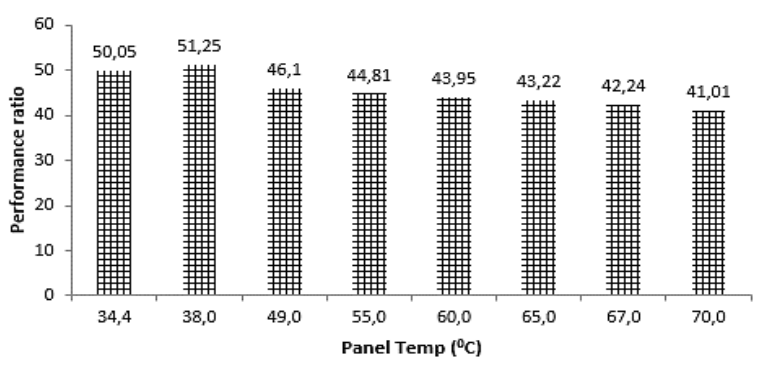

Figure 3. Performance ratio of the photovoltaic module with increasing temperature

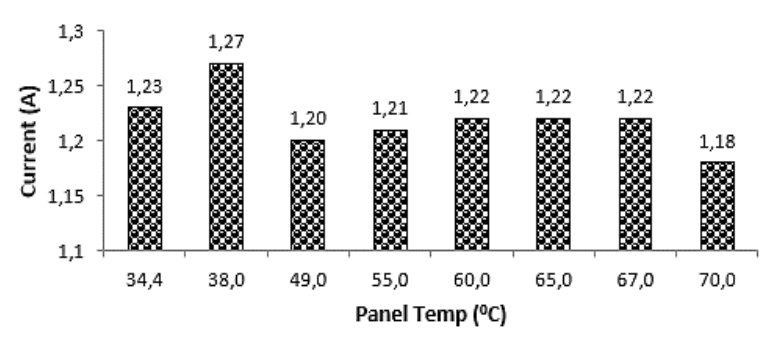

Figure 2. Current performance of the photovoltaic module with increasing temperature

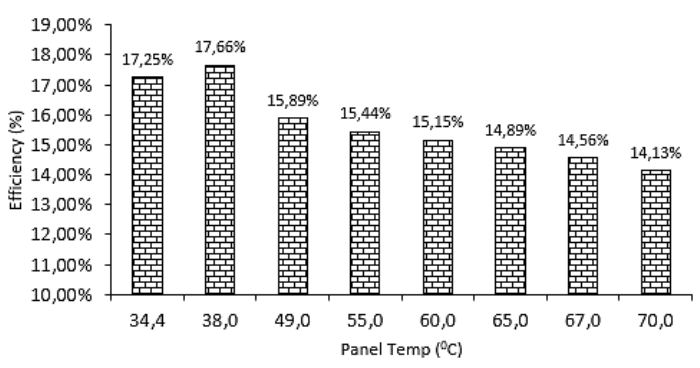

Figure 4. Efficiency of the photovoltaic module with increasing temperature 


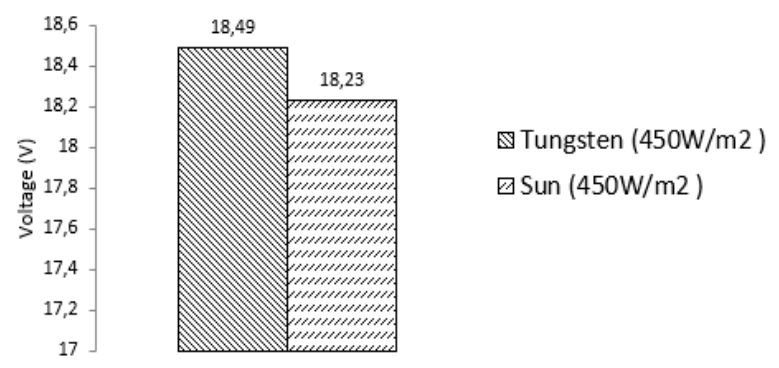

Figure 5. Voltage produced by the photovoltaic module under different sources of irradiance

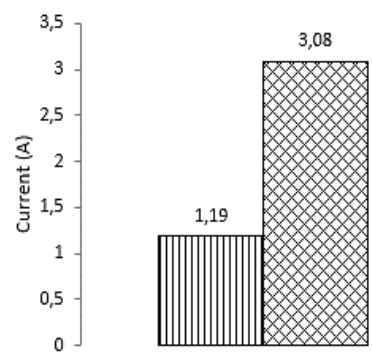

ए Tungsten $(450 \mathrm{~W} / \mathrm{m} 2)$

Figure 6. Current produced by the photovoltaic module under different sources of irradiance

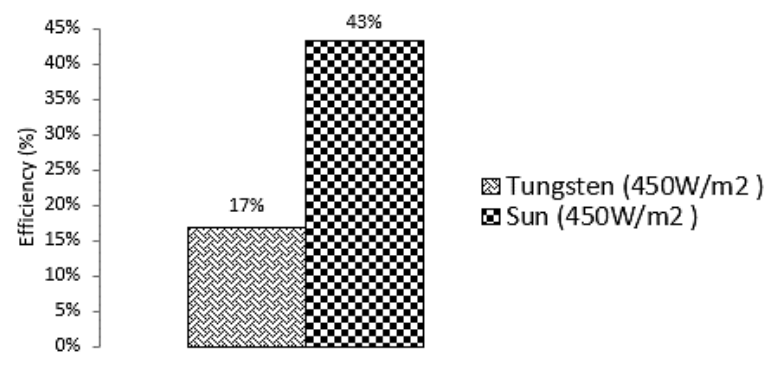

Figure 7. Efficiency of the photovoltaic module under different sources of irradiance

\section{CONCLUSIONS}

Solar cells, like all semiconductor materials, are highly sensitive to temperature. One of the parameters that is profoundly affected by temperature is the open-circuit voltage, which also influences the power and efficiency of the photovoltaic module. As the temperature of the solar cell rises, the bandgap of the semiconductor reduces, which can be viewed as the electrons in the material gaining more energy. Also, an increase in temperature enhances lattice vibration, which obstructs the free movement of charge carriers. Since solar cells are highly sensitive to temperature and part of the incident, solar radiation eventually becomes heat. It is essential to continually cool it to remove/transfer the extra or unwanted heat. Irrespective of the atmosphere in which a photovoltaic module is being installed, as long as the photovoltaic module receives enough solar radiation and its temperature does not exceed the maximum operating cell temperature, it will remain efficient coupled with a high-performance ratio. If artificial light is to be used for power generation from a photovoltaic solar panel, it should be ensured that every part of the photovoltaic module is wholly and evenly illuminated.

\section{REFERENCES}

[1] Q. M. Aish, "Temperature Effect on Photovoltaic Modules Power Drop," Al-Khwarizmi Engineering Journal, vol. 11, no. 2, pp. 62-73, 2015.

[2] V. J. Fresharaki, M. Dehghani and J. J. Fresharaki, "The Effect of Temperature on Photovoltaic Cell Efficiency," Proceedings on the ${ }^{1 s t}$ International Conference on Emerging Trends in Energy Conservation-ETEC Tehran, Tehran, Iran, pp. 1-6, 2011.

[3] A. J. Carr and T. L. Pryor, "A comparison of the performance of different PV module types in temperate climates," Solar Energy, vol. 76, no, 1-3, pp. 285-294, 2004.

[4] S. Natarajan, T. Mallick, M. Katz and S. Weingaertner, "Numerical investigations of solar cell temperature for photovoltaic concentrator system and without passive cooling arrangements," International Journal of Thermal Sciences, vol. 50, no. 12, pp. 2514-2521. 2011.

[5] M. Fuentes, G. Nofuentes, J. Aguilera, D. L. Talavera and M. Castro, "Application and validation of algebraic methods to predict the behavior of crystalline silicon PV modules in Mediterranean climates," Solar Energy, vol. 81, no. 11, pp. 1396-1408, 2007.

[6] M. Z. Jacobson and M. A. Delucchi, "Providing all global energy with wind, water and solar power. Part I: Technologies, energy resources, quantities and areas of infrastructure, and materials," Energy Policy, vol. 39, no. 3, pp.1154-1169, 2011.

[7] F. A. Kamgba, C. O. Edet and A. O. Njok, "Effects of some meteorological parameters on wind energy potential in Calabar, Nigeria," Asian journal of physical and chemical sciences, vol. 4, no. 1, pp. 1-7, 2017. 
[8] W. Xiao, N. Ozog and W. G. Dunford, "Topology Study of Photovoltaic Interface for Maximum Power Point Tracking,” IEEE Trans. Industrial Electronics, vol. 54, no. 3, pp. 1696-1704, 2007.

[9] IPCC, "Intergovernmental Panel on climate Change (IPCC)," Climate Change, 2001.

[10] World Energy Council, "Executive summary," Survey of Energy Resources, 2020.

[11] C. U. Ike, "The effect of temperature on the performance of a photovoltaic solar system in Eastern Nigeria," International Journal of engineering and Science, vol. 3, pp. 10-14, 2013.

[12] V. B. Omubo-pepple, C. Isreal-Cookey and G. I. Alaminokuma, "Effects of Temperature, Solar Flux and Relative Humidity on the Efficient Conversion of Solar Energy to Electricity," European Journal of Scientific Research, vol. 35, no. 2, pp. 173-180, 2009.

[13] A. O. Njok and J. C. Ogbulezie, "The Effect of Relative Humidity and Temperature on Polycrystalline Solar Panels Installed close to a River," Physical science International Journal, vol. 20, no. 4, pp. 1-11, 2018.

[14] M. T. Chaichan and H. A. Kazem, "Experimental analysis of solar intensity on photovoltaic in hot and humid weather conditions," International Journal of Scientific and Engineering Research, vol. 7, no. 3, pp. 91-96, 2016.

[15] A. El-Shaer, M. T. Tadros and M. A. Khalifa, "Effect of light intensity and temperature on crystalline silicon solar modules parameters," International Journal of Emerging Technology and Advanced Engineering, vol. 4, pp. 311-318, 2014.

[16] D. V. Tobnaghi and D. Naderi, "The effect of solar radiation and temperature on solar cells performance," Extensive Journal of Applied Sciences, vol. 3, pp. 39-43, 2015.

[17] A. Gaur and G. N. Tiwari, "Performance of photovoltaic modules of different solar cells," Journal of Solar Energy, vol. 2013, pp. 1-13, 2013.

[18] S. P. Rani, S. M. Giridhar and S. R. Prasad, "Effect of temperature and irradiance on solar module performance," IOSR Journal of Electrical and Electronics Engineering, vol. 13, no. 2, pp. 36-40, 2018.

[19] Z. Syafiqah, Y. M. Irwan, N. A. M. Amin, M. Irwanto, W. Z. Leow, and A. R. Amelia, "Thermal and Electrical Study for PV Panel with Cooling System," Indonesian Journal of Electrical Engineering and Computer Science, vol. 7, no. 2, pp. 492-499, 2017.

[20] A. R. Amelia, Y. M. Irwan, W. Z. Leow, M. Irwanto, I. Safwati and M. Zhafarina, "Investigation of the Effect of Temperature on Photovoltaic (PV) Panel Output Performance," International Journal on Advanced Science Engineering Information Technology, vol. 6, no. 5, pp. 682-688, 2016.

[21] W. Z. Leow, Y. M. Irwan, M. Asri, M. Irwanto, A. R. Amelia, Z. Syafiqah and I. Safwati, "Investigation of solar panel performance based on different wind velocity using ANSYS," Indonesian Journal of Electrical Engineering and Computer Science (IJEECS), vol. 1, no. 3, pp. 456-463, 2016.

[22] A. O. Njok, J. C. Ogbulezie, M. K. Panjwani and R. M. Larik, "Investigation of Monthly Variations in the Efficiencies of Photovoltaics due to Sunrise and Sunset Times," Indonesian Journal of Electrical Engineering and Computer Science (IJEECS), vol. 18, no. 1, pp. 310-317, 2020.

[23] A. O. Njok, F. A. Kamgba, M. K. Panjwani and F. H. Mangi, "The influence of solar power and solar flux on the efficiency of polycrystalline photovoltaics installed close to a river," Indonesian Journal of Electrical Engineering and Computer Science (IJEECS), vol. 17, no. 2, pp. 988-996, 2020.

[24] R. Verayiah and A. Iyadurai, "A Comparison Study on Types of PV for Grid Connected Photovoltaic Power," Indonesian Journal of Electrical Engineering and Computer Science (IJEECS), vol. 6, no. 2, pp. 349-356, 2017.

[25] T. M. N. T. Mansur, N. H. Baharudin and R. Ali, "Performance Analysis of Self-Consumed Solar PV System for a Fully DC Residential House," Indonesian Journal of Electrical Engineering and Computer Science (IJEECS), vol. 8, no. 1, pp. 391-398, 2017.

[26] M. Boxwell, "Solar Electricity Handbook: A simple, practical guide to solar energy - designing and installing photovoltaic solar electric systems (6 ${ }^{\text {th }}$ ed.)," United Kingdom: Greenstream Publishing, pp. 409, 2012.

[27] A. B. Muhammad, M. A. Hafiz, K. Shahid, A. Muzaffar and M. S. Aysha, "Comparison of performance measurements of photovoltaic modules during winter months in Taxila, Pakistan," International Journal of Photoenergy, vol. 2014, pp. 1-8, 2014. 